\title{
Revised STREAM Code and WASP5 Benchmark (U)
}

by

K. F. Chen

Westinghouse Savannah River Company

Savannah River Site

Aiken; South Carolina 29808

DOE Contract No. DE-AC09-89SR18035

This paper was prepared in connection with work done under the above contract number with the U.S. Department of Energy. By acceptance of this paper, the publisher and/or recipient acknowledges the U.S. Government's right to retain a nonexclusive, royalty-free license in and to any copyright covering this paper, along with the right to reproduce and to authorize others to reproduce all or part of the copyrighted paper.

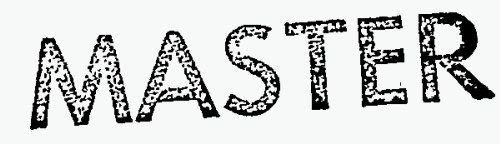

DISTRIBUTION OF THIS DOCUMENT IS UNLMMTED 


\section{REVISED STREAM CODE AND WASP5 BENCHMARK (U)}

Kuo-Fu Chen

Technical Review

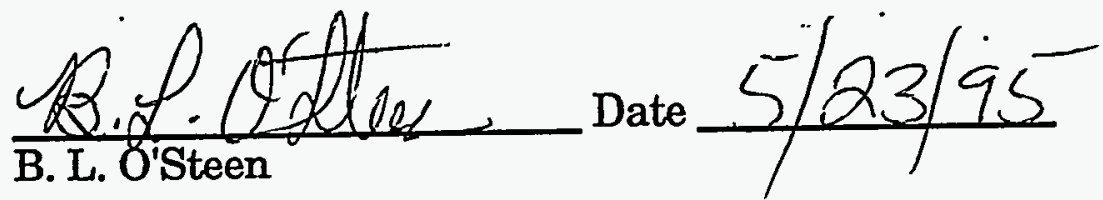

Approvals

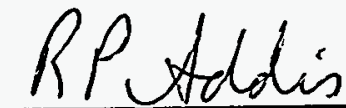

R. P. Addis, Manager ETG

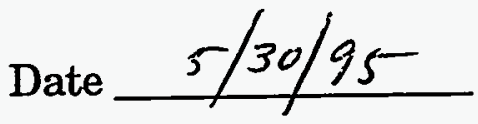

\footnotetext{
$\frac{\text { A. Boni, Manager ETS }}{\text { L. Bun }}$
}

Date $6-2-95$

May 1995

Westinghouse Savannah River Company

Savannah River Site

Alken, SC 29808

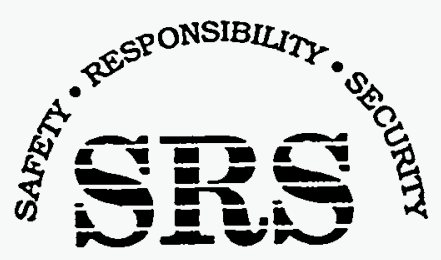

SAVANNAH RIVER SITE

PREPARED FOR THE U.S. DEPARTMENT OF ENERGY UNDER CONTRACT NO. DE-AC09-89SR18035 


\section{DISCLAMMER}

This report was prepared as an account of work sponsored by an agency of the United States Government. Neither the United States Government nor-any agency thereof, nor any of their employees, makes any warranty, express or implied, or assumes any legal liability or - responsibility for the accuracy, completeness, or usefilness of any information, apparatus, product, or process disclosed, or represents that its use would not infinge privately owned rights. Reference herein to any specific commercial product, process, or service by trade name, trademark, manufacturer, or otherwise does not necessarily constitute or imply its endorsement, recommendation, or favoring by the United States Government ar any agency thereof. The views and opinions of authors expressed herein do not necessarily state or reflect those of the United States Government or any agency thereof.

This report has been reproduced directly from the best available copy.

Available to DOE and DOE contractors from the Office of Scientific and Technical Information, P.O. Box 62, Oak Ridge, TN 37831; prices available from (615) 576-8401.

Available to the public from the National Technical Information Service, U.S. Department of Commerce, 5285 Port Royal Road, Springfield, VA 22161. 


\section{DISCLAIMER}

Portions of this document may be illegible in electronic image products. Images are produced from the best available original document. 
Key Words STREAM

WASP5

Dye Study

Benchmark

Emergency Response

Retention:-Lifetime

\section{REVISED STREAM CODE AND WASP5}

BENCHMARK (U)

Kuo-Fu Chen

Issued: May 1995

SRTC

SAVANNAH RIVER TECHNOLOGY CENTER

AIKEN, SC 29808

Westinghouse Savannah River Company Savannah River Site

Aiken, SC 29808

PREPARED FOR THE U.S. DEPARTMENT OF ENERGY UNDER CONTRACT NO. DE-AC09-89SR18035 


\section{ABSTRACT}

STREAM is an emergency response code that predicts downstream pollutant concentrations for releases from the SRS area to the Savannah River. The STREAM code uses an algebraic equation to approximate the solution of the one dimensional advective transport differential equation. This approach generates spurious oscillations in the concentration profile when modeling long duration releases. To improve the capability of the STREAM code to model long-term releases, its calculation module was replaced by the WASP5 code. WASP5 is a US EPA water quality analysis program that simulates one-dimensional pollutant transport through surface water. Test cases were performed to compare the revised version of STREAM with the existing version. For continuous releases, results predicted by the revised STREAM code agree with physical expectations.

The WASP5 code was benchmarked with the US EPA 1990 and 1991 dye tracer studies, in which the transport of the dye was measured from its release at the New Savannah Bluff Lock and Dam downstream to Savannah. The peak concentrations predicted by the WASP5 agreed with the measurements within $\pm 20.0 \%$. . The transport times of the dye concentration peak predicted by the WASP5 agreed with the measurements within $\pm 3.6 \%$. These benchmarking results demonstrate that STREAM should be capable of accurately modeling releases from SRS outfalls. 
Waste Management and

\section{TABLE OF CONTENTS}

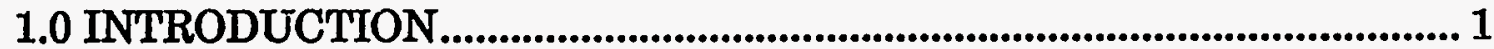
2. COMPARISONS BETWEEN THE OLD AND REVISED STREAM

CODES.

3. BENCHMARK WITH DYE TRACER STUDY DATA …........................ 2

4. CONCLUSIONS ...................................................................................... 5

REFERNCES 
LIST OF TABLES

Table 1 Savannah River Freshwater Modeling Project Geometry Data 6

Table 2 Model Comparison Summary

\section{IIST OF FIGURES}

Figure 1 Calculated Concentrations at Highway 301 (Constant Release Rate of $0.5 \mathrm{~kg} / \mathrm{min}$ from $\mathrm{H}$-Area) ........................................................8

Figure 2 Calculated Concentrations at Highway 119 (Constant Release Rate of $0.5 \mathrm{~kg} / \mathrm{min}$ from $\mathrm{H}$-Area)

Figure 3 Calculated Concentrations at Highway Beaufort-Jasper

(Constant Release Rate of $0.5 \mathrm{~kg} / \mathrm{min}$ from $\mathrm{H}$-Area). 10

Figure 4 Calculated Concentrations at Savannah Water Plant

(Constant Release Rate of $0.5 \mathrm{~kg} / \mathrm{min}$ from H-Area)

Figure 5 Measured Dye Tracer Profiles at the Sampling Stations (US EPA 1990 Dye Tracer Study)

Figure 6 Measured Dye Tracer Profiles at the Sampling Stations (US EPA 1991 Dye Tracer Study)

Figure 7 Area under the Measured Dye Concentration Curves (US EPA 1990 Dye Tracer Study)

Figure 8 WASP5 Simulation for US EPA 1990 Dye Tracer Study 15

Figure 9 WASP5 Simulation for US EPA 1991 Dye Tracer Study 16

Figure 10 WASP5 Calculation for the Dye Concentrations at Poor Robin Landing (SR-22) Assuming that the Additional Dye Were Released at 12

Figure 11 Total Concentrations at Poor Robin Landing (SR-22) Would be Calculated by WASP5 If the Input of the Additional Dye Release Time Were at 16.

Figure 12 Confirmation 19 


\title{
REVISED STREAM CODE AND WASP5 BENCHMARK (U)
}

\author{
By Kuo-Fu Chen \\ Westinghouse Savannah River Company \\ Savannah River Site \\ Aiken, SC 29808
}

\subsection{INTRODUCTION}

STREAM is an emergency response code that predicts downstream pollutant concentrations for releases from the SRS area to the Savannah River. The STREAM code uses an algebraic equation to approximate the solution of the one dimensional advective transport differential equation. The advantage of this simplified approach is that the time required to obtain a solution is shortened to a matter of minutes. However, this approach generates spurious oscillations in the concentration profile when modeling long duration releases.

To improve the capability of the STREAM code to model long-term releases, its calculation module was replaced by the WASP5 code [1]. WASP5 is a US EPA water quality analysis program that simulates one-dimensional pollutant transport through surface water. WASP5 uses a finite difference method to solve the advective transport equation.

Test cases were performed to compare the revised version of STREAM with the existing version. These test cases simulated pollutant transport to Savannah via the Savannah River for releases from the H-Area outfall. For continuous releases, results predicted by the revised STREAM code agree with physical expectations.

The WASP5 code was benchmarked with the US EPA 1990 and 1991 dye tracer studies, in which the transport of the dye was measured from its release at the New Savannah Bluff Lock and Dam downstream to Savannah. The peak concentrations predicted by the WASP5 agreed with the measurements within $\pm 20.0 \%$. The transport times of the dye concentration peak predicted by the WASP5 agreed with the measurements within $\pm 3.6 \%$. These benchmarking results demonstrate that STREAM should be capable of accurately modeling releases from SRS outfalls.

\section{COMPARISONS BETWEEN THE OLD AND REVISED STREAM CODES}

Test cases were performed to compare the revised version of STREAM containing WASP5 with the previous version. These test cases simulated the pollutant transport to Savannah by way of the Four Mile Branch and the Savannah River for releases from the H-Area outfall. Conditions tested were 
a constant release rate of $0.5 \mathrm{~kg} / \mathrm{min}$ with various release durations. Downstream pollutant concentrations calculated by the previous version of STREAM fluctuated for releases longer than 600 minutes, as shown in Figures 1 to 4. These results are not physically realistic; the pollutant concentration should increase with time and gradually approach a steady state value. Figures 1 to 4 also show concentrations calculated by the revised STREAM code. These concentrations do asymptotically approach a steady state value as expected. The results of these simple test calculations demonstrate that the problem with long-term oscillations has been resolved in the revised version of STREAM.

\section{BENCHMARK WITH DYE TRACER STUDY DATA}

Before the revised version of STREAM is used for routine tracking of releases, it should be benchmarked with the results of dye tracer experiments. Tracer studies are planned to measure the transport characteristics of the streams inside the Savannah River Site (SRS). When these studies are completed, the data will be used to benchmark the pollutant transport codes. Meanwhile, there are two sets of dye tracer data currently available for benchmarking. These data are from studies conducted by the U.S. Environmental Protection Agency (US EPA), the South Carolina Department of Health and Environmental Control (SCDEHC), and the Georgia Department of Natural Resources (GDNR), with a goal of developing a waste load allocation model for the Savannah River. The Environmental Technology Section of SRTC participated in both studies. The benchmark with these two sets of dye tracer study data is presented in this report.

\section{U.S. EPA 1990 and 1991 Dye Tracer Studies}

In a 1990 dye tracer study, EPA personnel released 20 gallons $(85.496 \mathrm{~kg}$ ) of Rhodamine WT dye into the Savannah River below the New Savannah Bluff Lock and Dam at 12:00 on September 24. To assure that the peak could be measured all the way down to Savannah, Georgia, EPA personnel released an addtional 20 gallons of dye 20 yards downstream from the Highway 301 bridge at 11:45 on September 26 [2].

In a 1991 dye tracer study, EPA personnel released 20 gallons $(85.496 \mathrm{~kg}$ ) of Rhodamine WT dye into the Savannah River below the New Savannah Bluff Lock and Dam at 12:00 on September 5, and an additional 10 gallons of dye 20 yards downstream from the Highway 301 bridge at 16:00 on September 7 [2]. The additional releases were made when the dye concentration peaked at Highway 301 to reduce the amount of dye needed.

To determine the dye travel time, dye concentrations were measured at seven downstream sampling stations, shown in Table 1 [2]. All samples were taken by automatic field fraction collectors that were adjusted to take hourly samples during the period of peak concentrations, with extra samples taken near the beginning and end to assure complete coverage. A calibrated fluorimeter was used to measure the dye concentration in the water samples. 
Samples were not measured at some locations due to battery failure or sampler malfunction.

Figures 5 and 6 show the measured dye concentration as a function of time at each sampling station [2]. Generally, the measured peak concentration decreases with distance downstream. The increase in the measured dye concentration at Sampling Station SR-22 (Poor Robin Landing) results from the additional tracer released 20 yards downstream from Sampling-Station SR-18.

The amount of dye tracer passing a sampling station was estimated by integrating the area covered by the measured dye concentration curve. The integrated areas for $\mathbf{1 9 9 0}$ dye tracer study are presented in Figure 7. Figure 7 shows that the amount of tracer decreases as it travels downstream (The small increase in the tracer concentration at Sampling Station SR-14 might be due to measurement uncertainty, and the jump at Sampling Station. SR-22 resulted from the additional dye added downstream from SR-18). This apparent loss of tracer, which is not to be confused with normal dispersion, suggests that the dye somehow precipitates or disappears by some other. means as it travels downstream.

\section{WASP5 Model for Savannah River}

The revised STREAM code was developed to model the pollutant transport originating from outfalls inside the SRS boundary. The dye release point for the US EPA dye tracer studies was downstream from the New Savannah Bluff Lock and Dam, outside the SRS boundary. Therefore, the standalone version of the WASP5 code was used to model the EPA dye tracer studies. The calculation modules of the revised STREAM code are an identical copy of the WASP5 code. Therefore, it is reasonable to assume that benchmarking the standalone version of WASP5 is equivalent to benchmarking the revised version of STREAM. Details of the WASP5 model follow.

River Geometry

WASP5 was used to model the Savannah River from the New Savannah Bluff Lock and Dam to a point nine river miles upstream from Fort Pulaski. The average river width was assumed to be $53.64 \mathrm{~m}(176 \mathrm{ft})$ and the average river depth was assumed to be $5.18 \mathrm{~m}$ (17 ft). The reach was divided into 550 segments with a segment length of $500 \mathrm{~m}$ (0.31 mile).

River Flow

The measured daily averaged flows of the Savannah River at the Augusta, Georgia, gauge station were used as input conditions for the WASP5 model. Daily averaged flows from September 24, 1990, to October 3, 1990, and from September 4, 1991, to September 11, 1991, were obtained from the U.S. Geological Survey Water Resources Data in South Carolina. 


\section{Comparisons}

Figure 8 compares the results of the WASP5 simulation with the US EPA 1990 dye tracer measurements. The peak concentrations at the sampling stations predicted by WASP5 agree with the measurements within $\pm 20.0 \%$, as shown in Table 2. Table 2 also shows that the transport times of the concentration peak predicted by the WASP5 agree with the measurements within $\pm 3.6 \%$.

Figure 9 compares the results of the WASP5 simulation with the US EPA 1991 dye tracer measurements. The differences between the calculated and measured dye concentrations at Sampling Stations SR-22, 25, 27, and 29 are above 29\%, as shown in Figure 9 and Table 2. An explanation of the cause of these discrepancies follows.

For instant releases (WASP5 calls it non-point source loading), WASP5 requires that the time intervals between the releases must be an integer factor of 24 hours. In the 1990 dye tracer study, the initial dye tracer was released at the New Savannah Bluff Lock and Dam at 12:00 on September 24, and additional dye was released downstream from US Highway 301 at 11:45 on September 26. The WASP5 code reassigns the additional release a time of 12:00 on September 26, 1990, giving a 15-minutes mismatch between the US EPA dye tracer study and the WASP5 model simulation. The error caused by this mismatch is small, because the dye transport time ( $>24$ hours) is large in comparison. In the1991 dye tracer study, the initial dye tracer was released at the New Savannah Bluff Lock and Dam at 12:00 on September 5, 1991 , and additional dye was released downstream from US Highway 301 at 16:00 on September 7, 1991. In this case, WASP5 reassigns the additional release a time of 12:00 on September 7, generating a four-hour mismatch between the WASP5 simulation and the US EPA dye tracer study. The error caused by this mismatch is large because it is comparable to the dye transport time.

An addtional case was run to examine the effect of this input time mismatch. For this case, it was assumed that the additional tracer was released at 12:00 on September 8. Figure 10 shows the resulting concentration profile at Sampling Station SR-22 (Poor Robin Landing). The first concentration peak contains the initial release of dye, and the second peak contains the additional release. Shifting the second peak 20 hours back in time (to the left) and superimposing it on the first peak as shown in Figure 11, produces the dye concentration profile that would be calculated by WASP5 if the additional release occurred at 16:00 on September 7. Figure 12 compares the peak concentration calculated by this method with the measured peak concentration at SR-22. As this figure shows, using this superposition method, the difference between the measured and calculated concentration peak reduces from $-29.24 \%$ to $-12.65 \%$. 


\section{CONCLUSIONS}

The calculation module of the STREAM code was replaced by the WASP5 code. Test cases were run to compare existing and revised versions of STREAM. These test cases simulated pollutant transport to Savannah by way of Four Mile Branch and the Savannah River following releases from the H-Area outfall. For continuous releases, the results predicted by the revised STREAM code agreed with physical expectations.

WASP5 was benchmarked with the US EPA 1990 and 1991 dye tracer studies. The peak concentrations at the sampling stations predicted by the WASP5 agree with the measurements within $\pm 20.0 \%$. WASP5 predicts the peak dye concentration transport times within $\pm 3.6 \%$.

For instant releases (WASP5 calls it non-point source loading), WASP5 requires that the time intervals between the releases must be an integer factor of 24 hours. This limits the accuracy of the WASP5 predictions for the cases of multiple releases at different times. When the time interval between two releases is other than an integer factor of 24 hours, the results predicted by WASP5 will contain a large error. It is recommended that EPA be informed of this shortcoming.

\section{REFERENCES}

1. Ambrose, Robert B., Wool, Tim A. and Martin, James L., "The Water Quality Analysis Simulation Program, WASP5, Part A: Model Documentation; Part B: Input Dataset," Environmental Research Laboratory, Office of Research and Development, U.S. Environmental Protection Agency, Athens, Georgia, September 20, 1993.

2. Private communication, Mark Koening, U.S. Environmental Protection Agency, Environmental Services Division, Athens, Georgia. 
Table 1 Savannah River Freshwater Modeling Project Geometry Data [2]

\begin{tabular}{|c|c|c|}
\hline Station & Location & Rivermile \\
\hline SR-1 & Clarks Hill Dam & 212.99 \\
\hline SR-9 & Below Savannah Bluff Lock \& Dam & 179.26 \\
\hline SR-12 & Shell Bluff Landing & 156.06 \\
\hline SR-14 & Brighams Landing & 138.47 \\
\hline SR-18 & US HWY 301Bridge/Burtons Ferry Landing & 114.24 \\
\hline SR-22 & Poor Robin Landing & 83.30 \\
\hline SR-25 & GA Highway 119 \& Clyo & 59.75 \\
\hline SR-27 & Upstream Ebenezer Landing & 43.91 \\
\hline SR-29 & Becks Feryy Landing & 38.10 \\
\hline SR-31 & US HWY 17 Houliham Bridge & 21.50 \\
\hline & Fort Pulaski & 0.00 \\
\hline
\end{tabular}


Table 2 Model Comparison Summary

Station Peak Concentration (ppb)

$$
\text { Meas. Calc. }
$$

\%Error

1990 Dye Tracer Study:

$\begin{array}{llll}\text { SR-12 } & 27.50 & 27.74 & 0.87 \\ \text { SR-14 } & 18.50 & 18.23 & -1.46 \\ \text { SR-18 } & 10.30 & 12.28 & 19.22 \\ \text { SR-22 } & 28.50 & 31.88 & 11.86 \\ \text { SR-25 } & 23.30 & 21.47 & -7.85 \\ \text { SR-27 } & 18.60 & 17.32 & -6.88 \\ \text { SR-29 } & : 16.10 & 16.04 & -0.37\end{array}$

1991 Dye Tracer Study:

\begin{tabular}{|c|c|c|c|c|c|c|}
\hline SR-12 & 24.806 & 26.52 & 6.91 & 19.0 & 18.78 & -1.16 \\
\hline SR-14 & 15.607 & 17.28 & 10.72 & 34.0 & 33.14 & \\
\hline SR-1 & 11.292 & 11.39 & 0.87 & $\mathbf{5 2 . 0}$ & 52.34 & 0.65 \\
\hline SR-2 & 20.295 & $14.36(17.728)$ & $-29.24(-12.65)$ & 75.0 & 72.54 & -3.28 \\
\hline SR-2 & 14.879 & 9.84 (11.998) & $-33.86(-19.36)$ & 93.0 & 94.12 & 1.20 \\
\hline SR-27 & 11.856 & $8.00(9.617)$ & $-32.56(-18.88)$ & 105.0 & 108.02 & 2.88 \\
\hline & 11.053 & 7.49 (8.904) & $-32.25(-19.44)$ & 110.0 & 112.86 & 2.60 \\
\hline
\end{tabular}

Arrivial Time (Hour)

Meas. Calc." \%Error

( ) adjusted 
Figure 1 Calculated Concentrations at Highway 301

(Constant Release Rate of $0.5 \mathrm{~kg} / \mathrm{min}$ from H-Area)

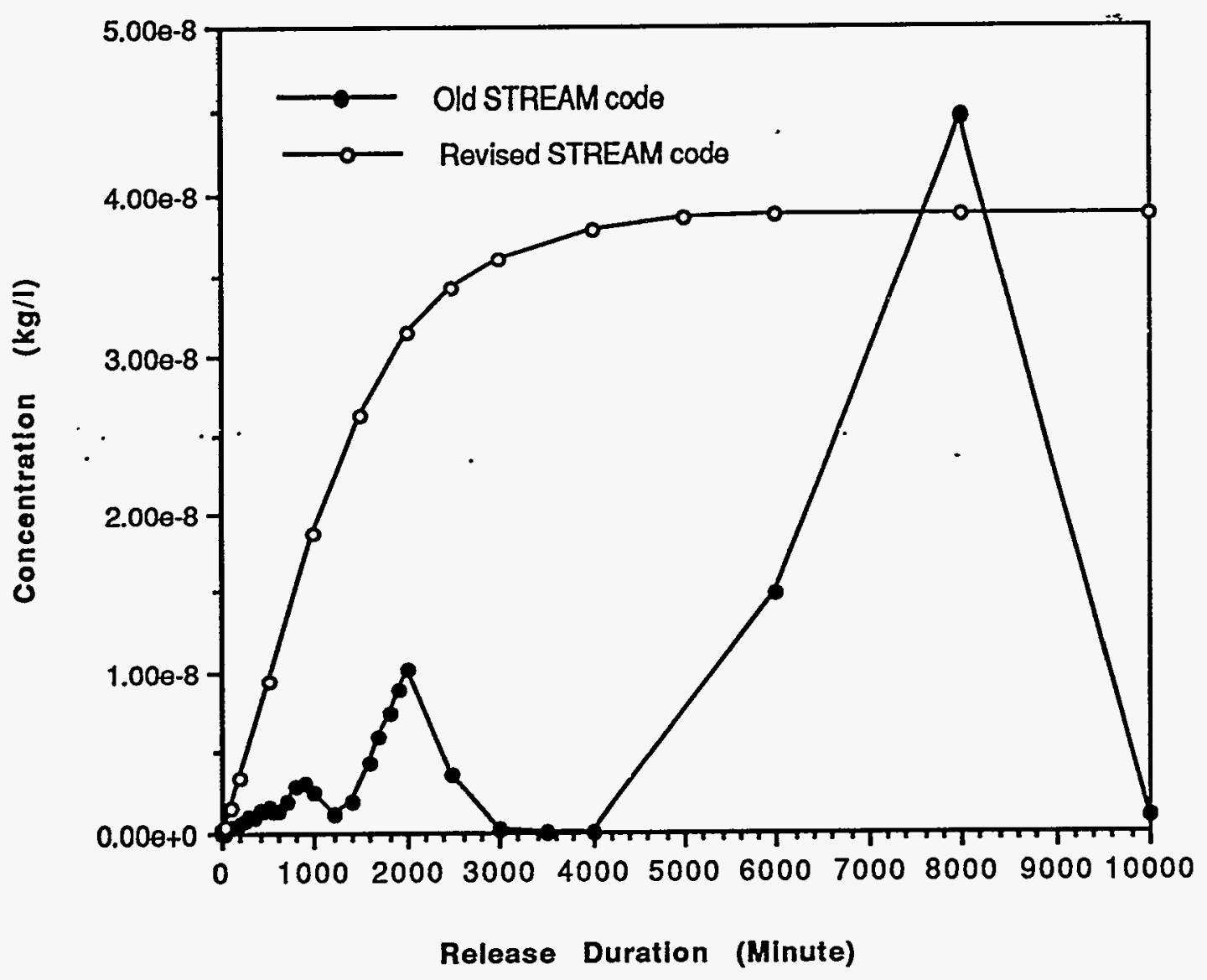


Figure 2 Calculated Concentrations at Highway 119

(Constant Release Rate of $0.5 \mathrm{~kg} / \mathrm{min}$ from $\mathrm{H}$-Area)

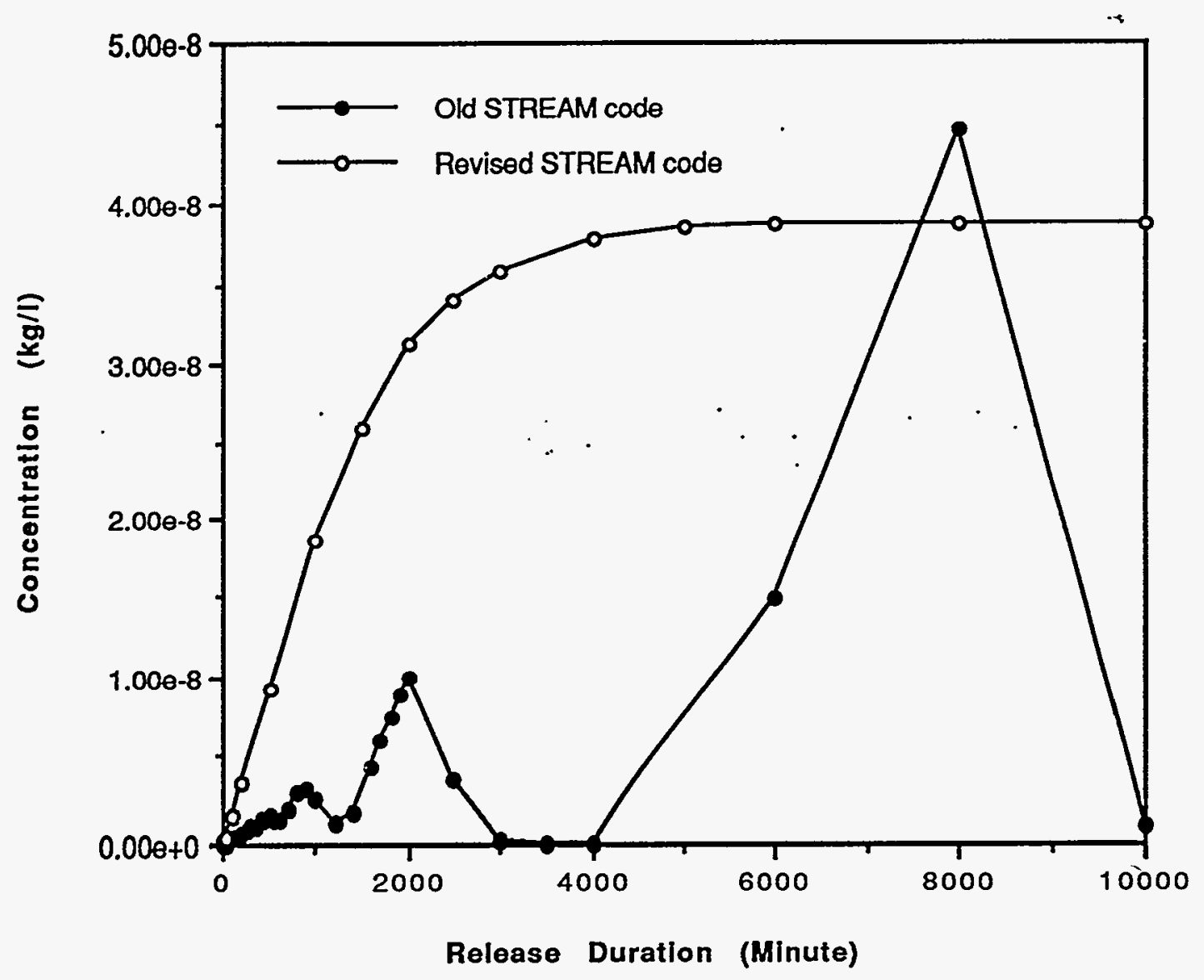


Figure 3 Calculated Concentrations at Highway Beaufort-Jasper (Constant Release Rate of $0.5 \mathrm{~kg} / \mathrm{min}$ from H-Area)

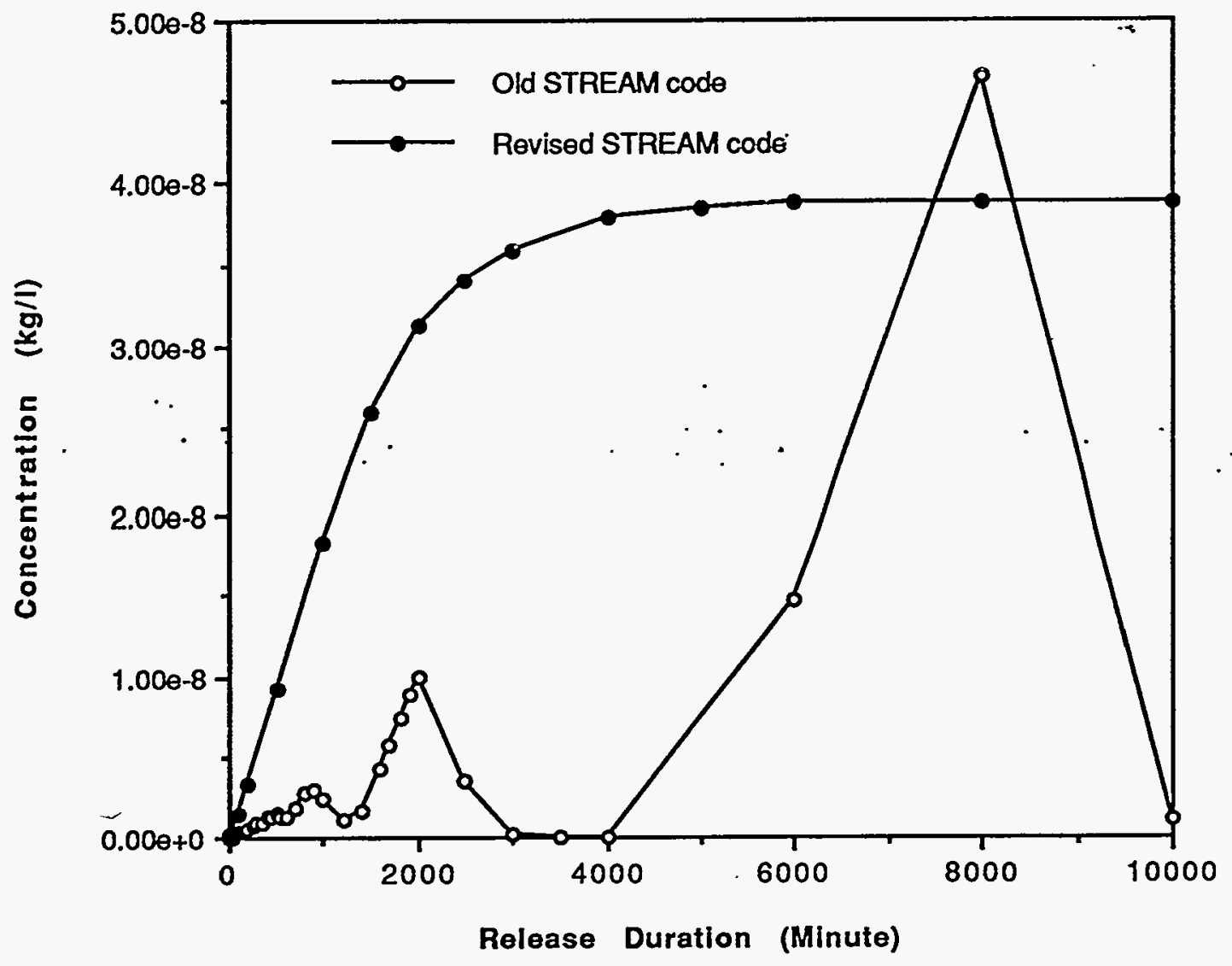


Figure 4 Calculated Concentrations at Savannah Water Plant

(Constant Release Rate of $0.5 \mathrm{~kg} / \mathrm{min}$ from $\mathrm{H}$-Area)

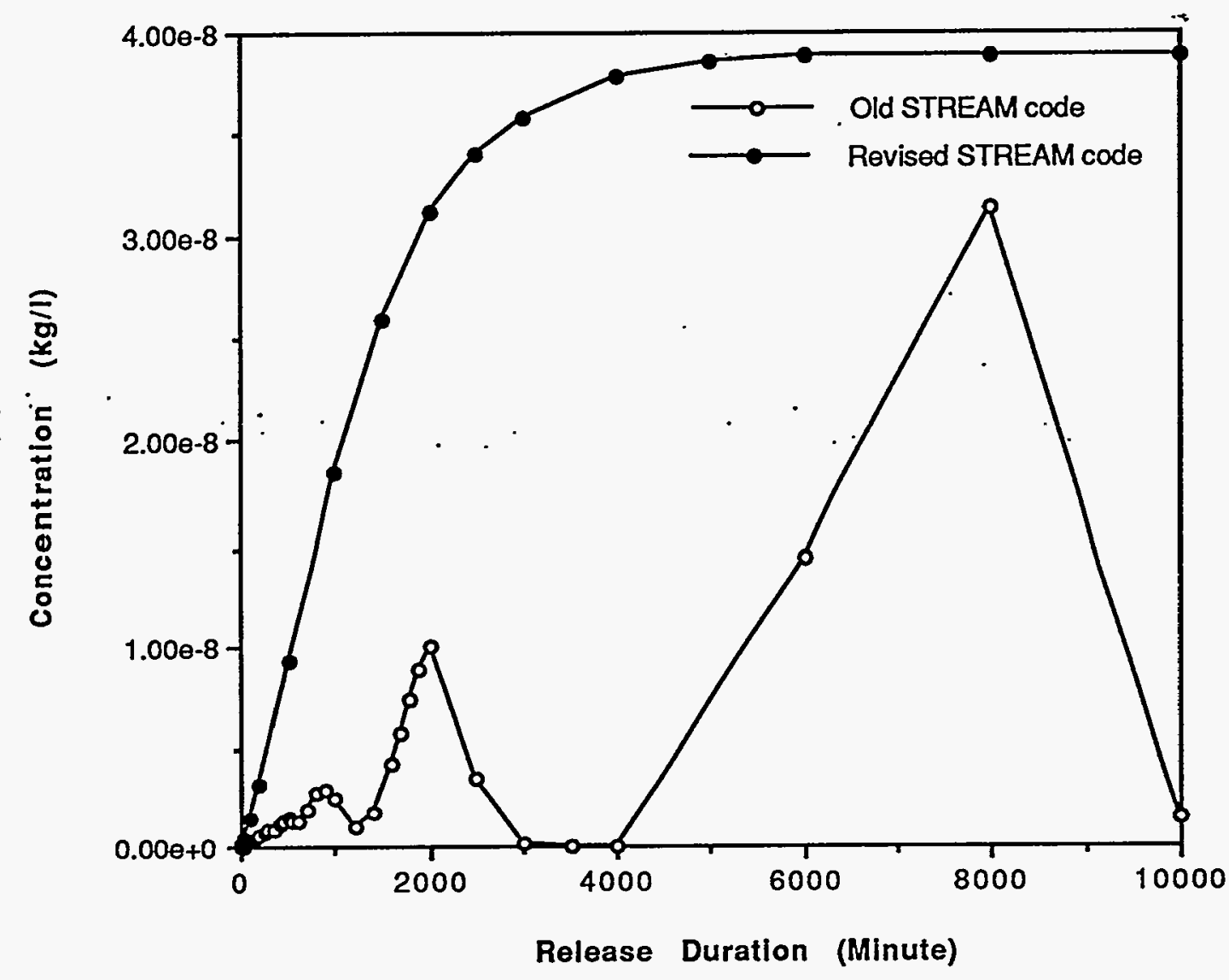


Figure 5 Measured Dye Tracer Profiles at the Sampling Stations (US EPA 1990 Dye Tracer Study)

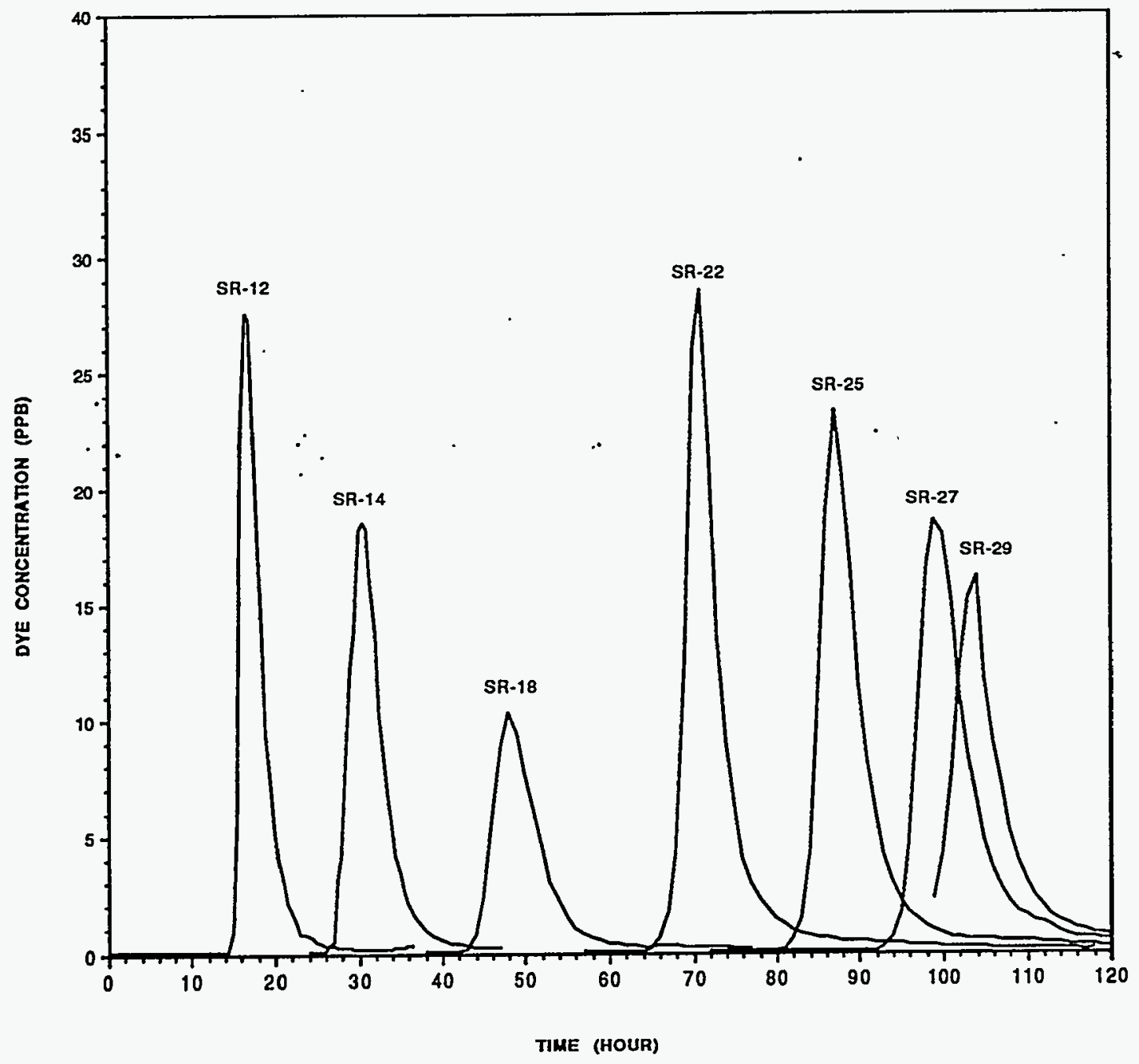


Figure 6 Measured Dye Tracer Profiles at the Sampling Stations (US EPA 1991 Dye Tracer Study)

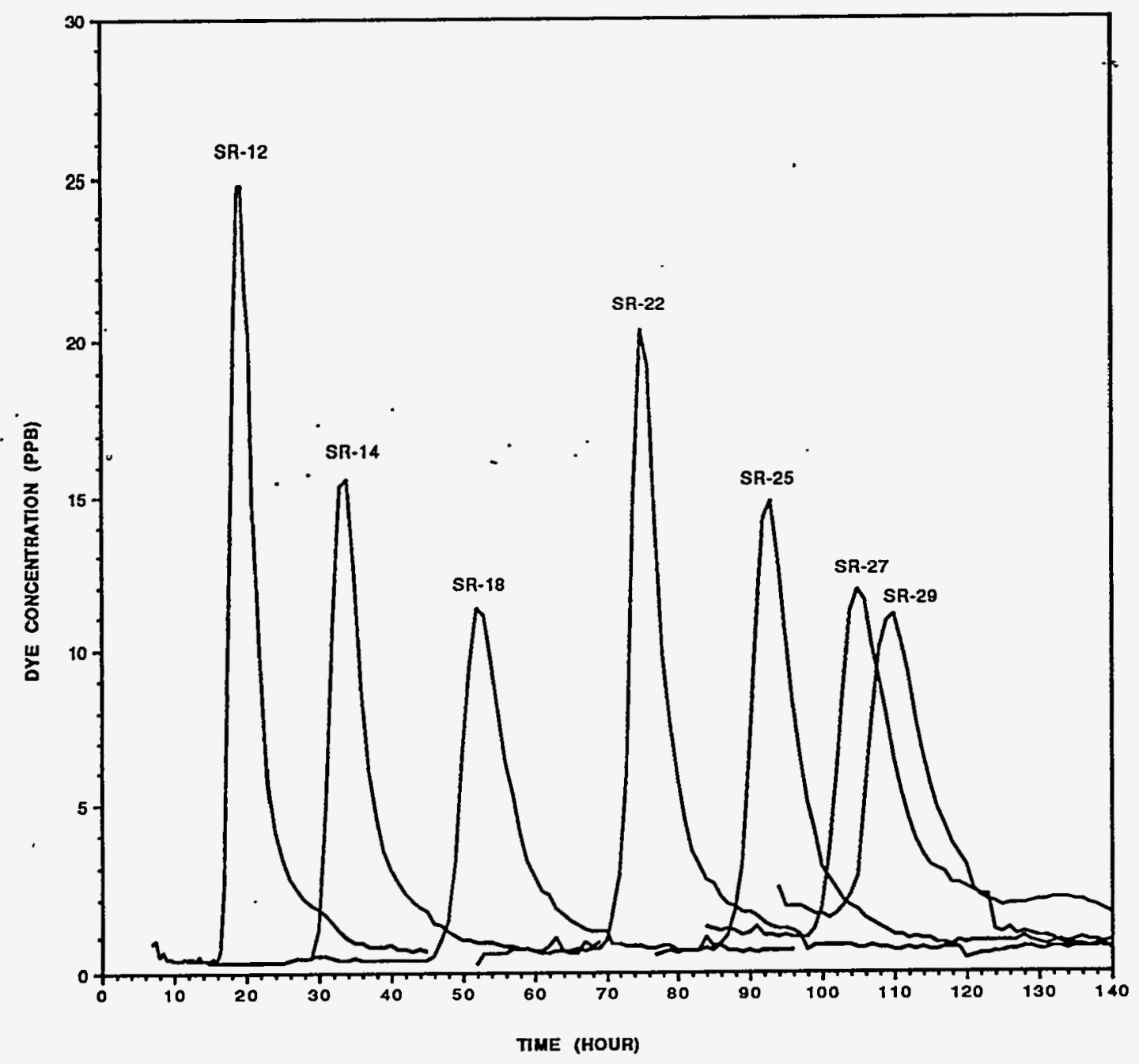


Figure 7 Area under the Measured Dye Concentration Curves (US EPA 1990 Dye Tracer Study)

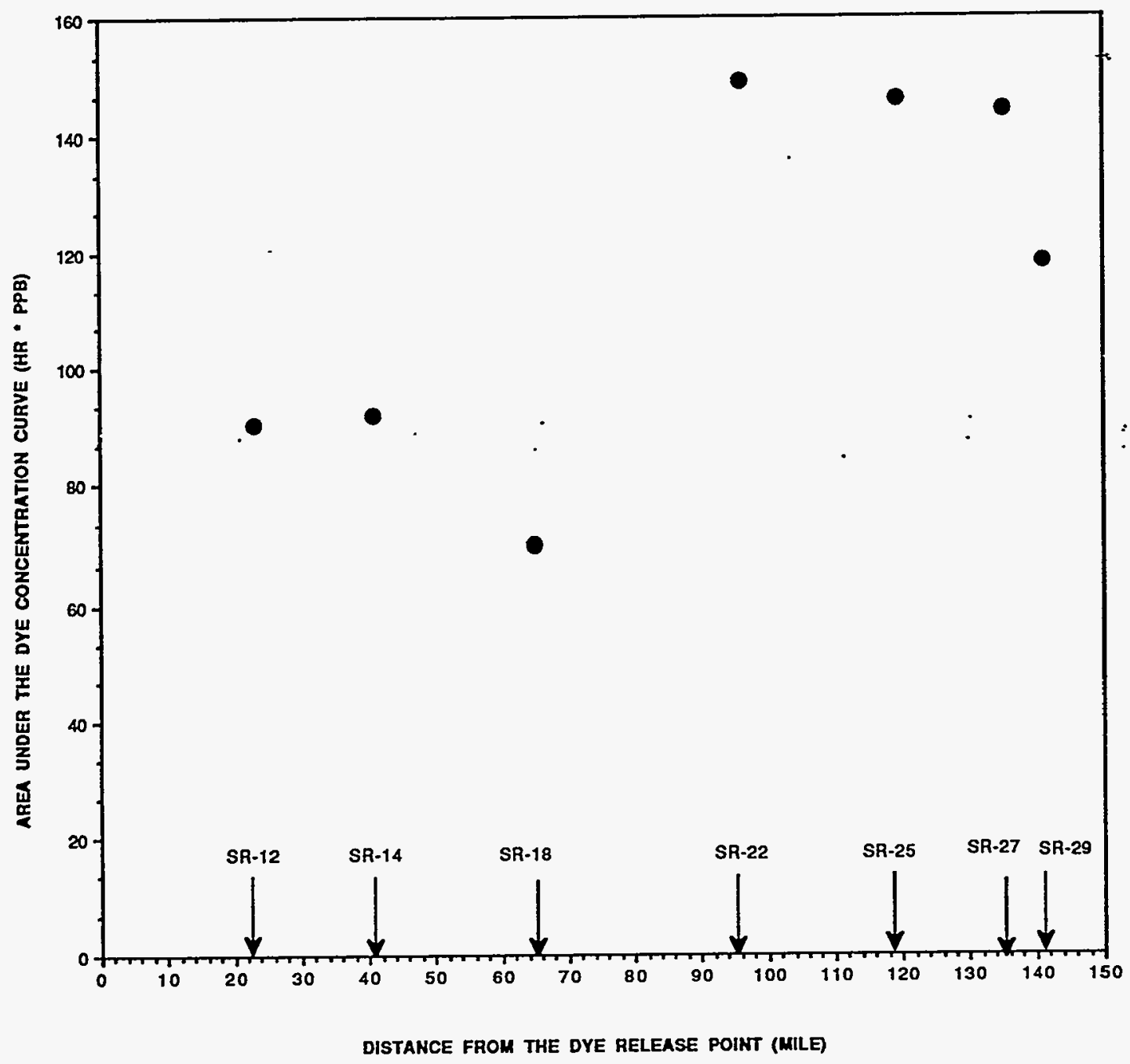


Figure 8 WASP5 Simulation for US EPA 1990 Dye Tracer Study

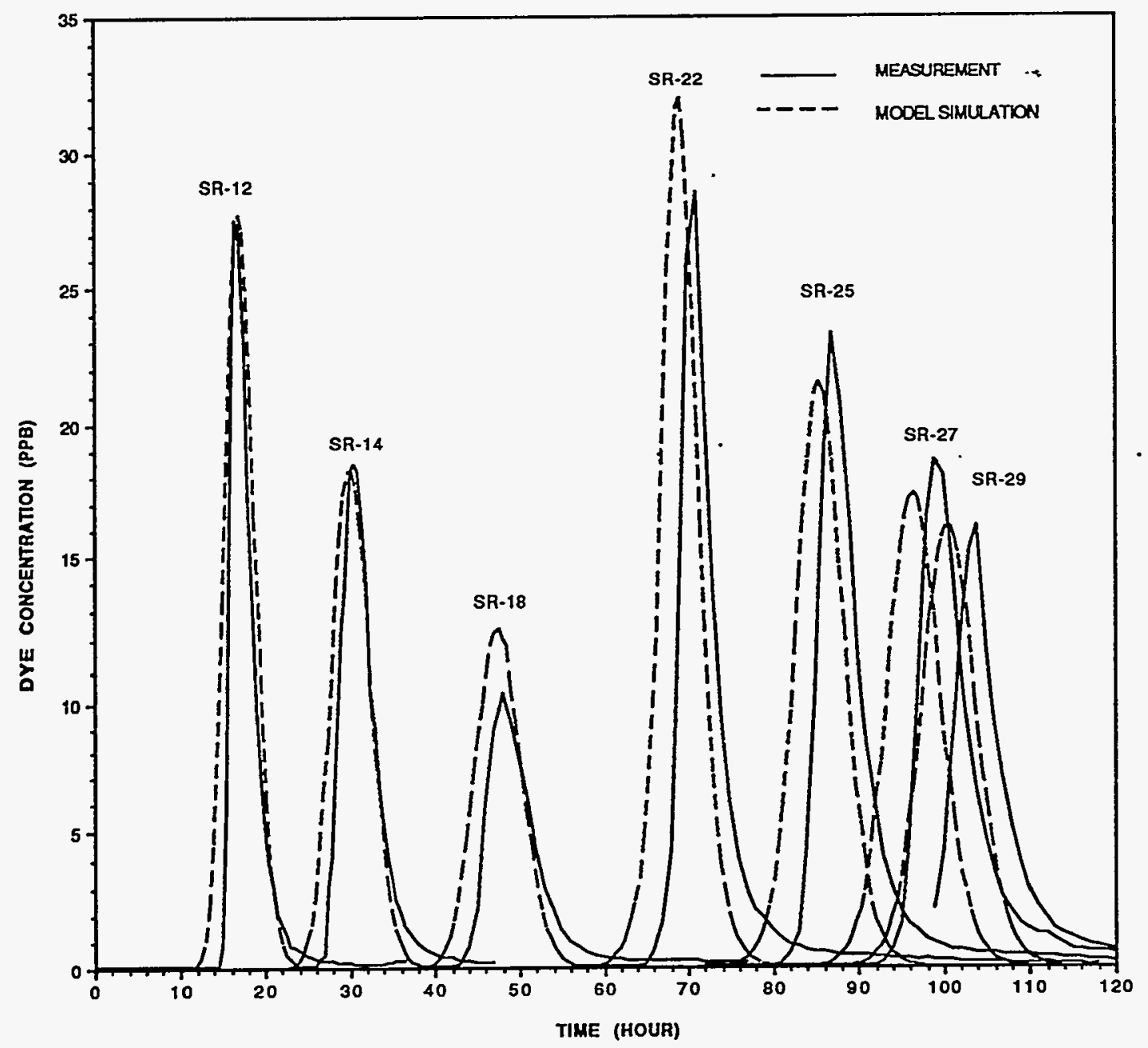

20 GALLONS OF DYE TRACER WERE RELEASED AT THE NEW SAVANNAH BLUFF LOCK \& DAM AT 12:00 ON SEPTEMBER 24, 1990. 20 GALLONS OF ADDITIONAL DYE TRACER WERE RELEASED AT US HIGHWAY 301 AT 11:45 ON SEPTEMBER 26,1990. 
Figure 9 WASP5 Simulation for US EPA 1991 Dye Tracer Study

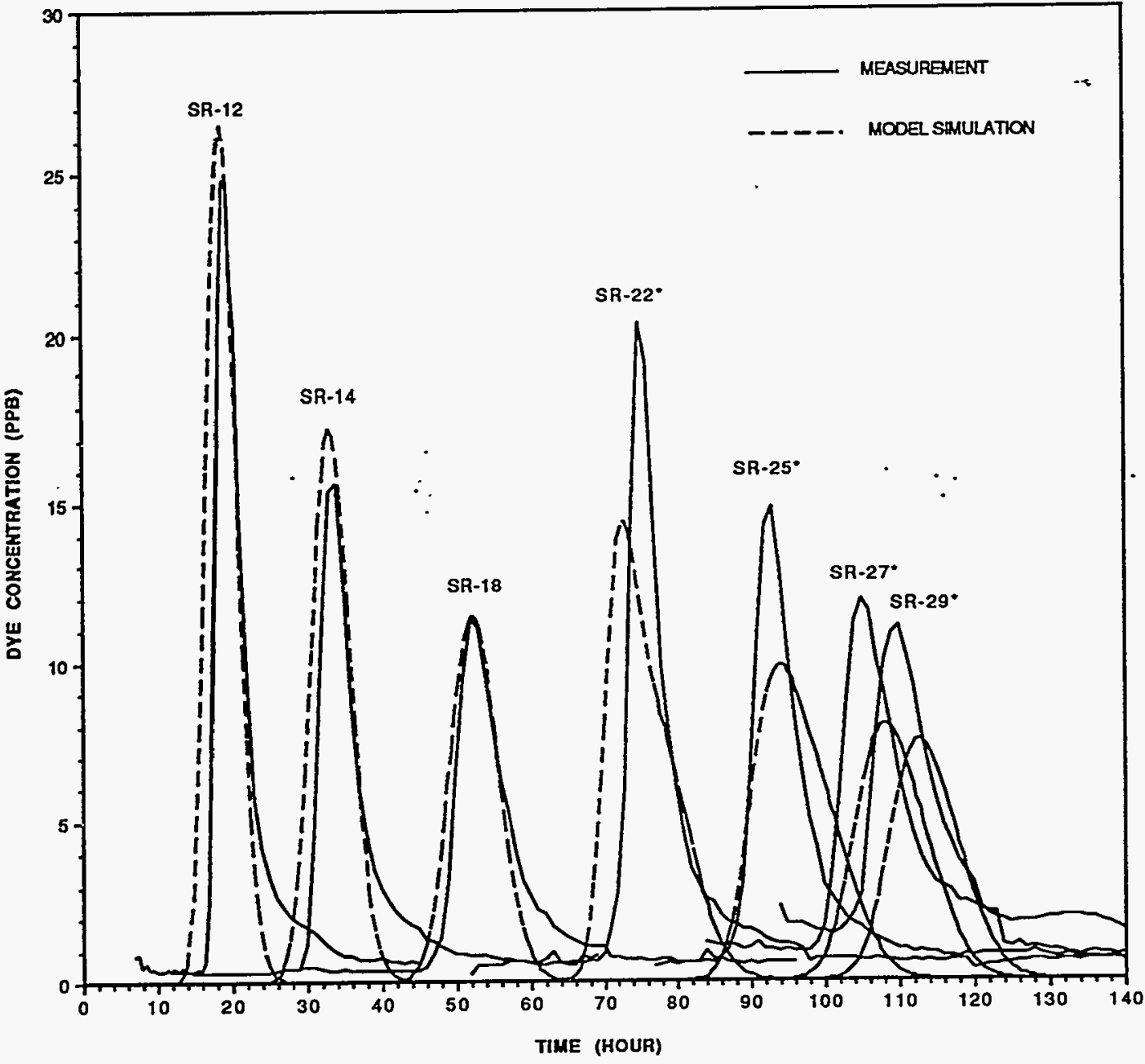

20 GALLONS DYE TRACER WAS RELEASED AT NEW SAVANNAH BLUFF LOCK \& DAM AT 12:00 ON SEPTEMBER 5, 1991. 10 GALLON OF DYE TRACER WAS RELEASED AT US HIGHWAY 301 AT 16:00 ON SEPTEMBER 7,1991.

- THE CAUSE OF THESE LARGE DISCREPANCIES IS EXPLAINED IN THE TEXT. 
Figure 10 WASP5 Calculation for the Dye Concentrations at Poor Robin Landing (SR-22)

Assuming that the Additional Dye Were Released at 12:00 on 9/8/91

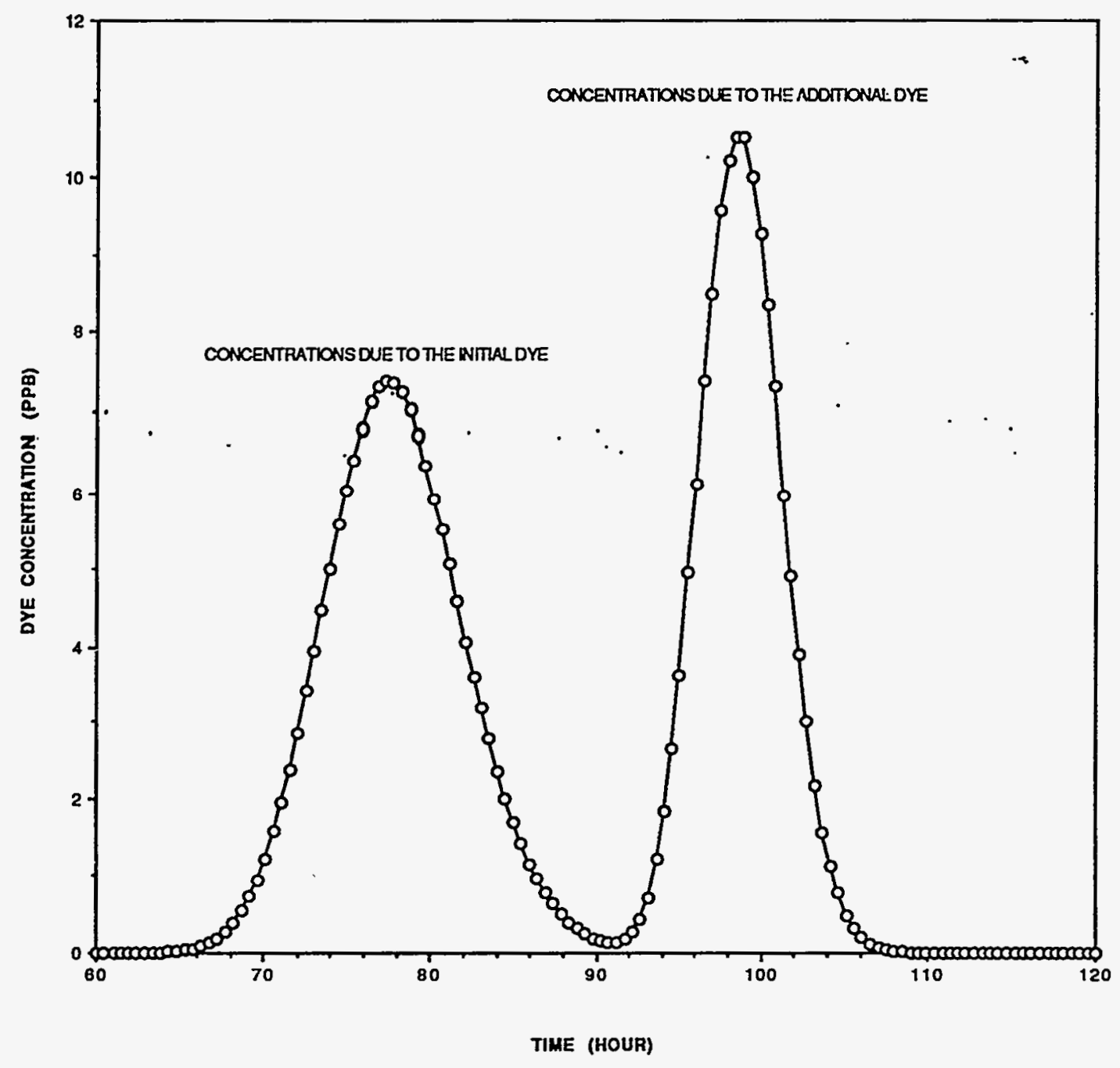


Figure 11 Total Concentrations at Poor Robin Landing (SR-22) Would be Calculated by WASP5 If the Input of the Additional Dye Release Time Were at $16: 00$ on $9 / 7 / 91$

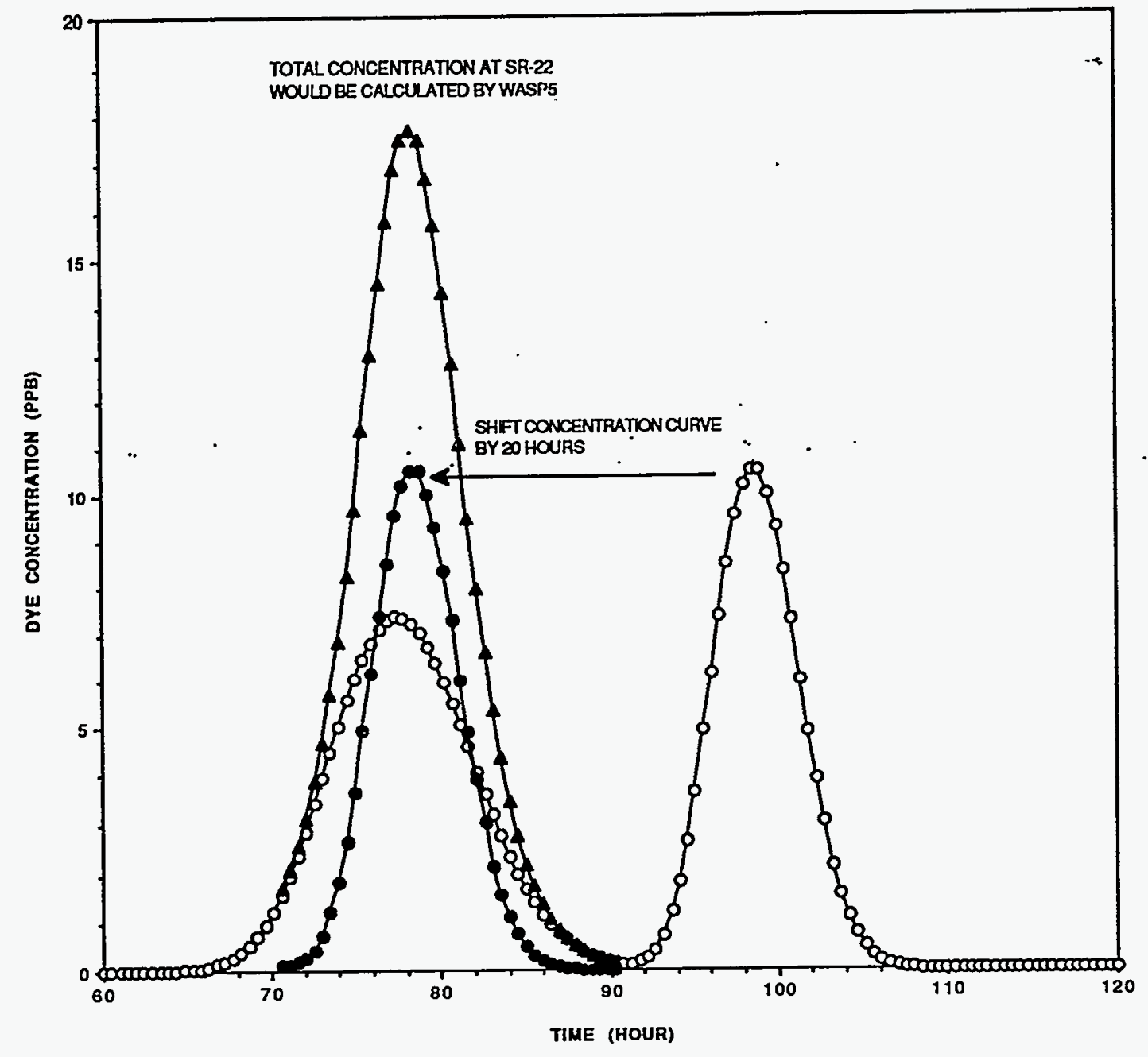


Figure 12 Confirmation

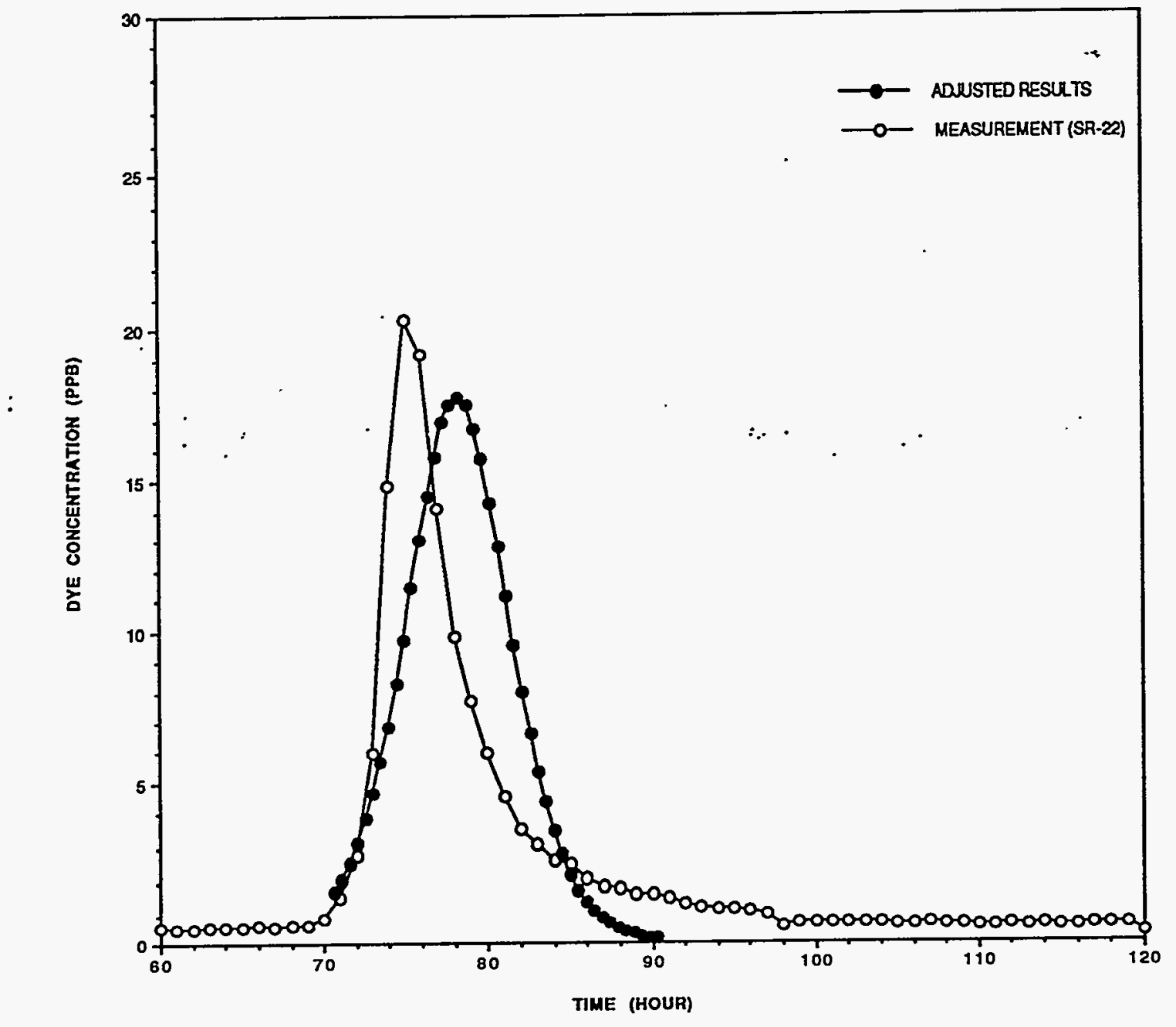




\section{REVISED STREAM CODE AND WASP5 BENCHMARK(U)}

\section{DISTRIBUTION}

R. P. Addis, 773-A

A. L. Boni, 773-A

W. A. Emel, 735-A

B. L. O'Steen, 773-A

A. J. Garrett, 773-A

D. W. Hayes, 735-A

Kuo-Fu Chen, 773-A

SRTC Records(4), 773-52A

ETG Records(5), 773-A 